$2^{12-7}$

th. 2448

19 RFP-1985

RFP-1985

January 24, 1973

THE HEATS OF SOLUTION OF BERYLLIUM IN

CHEMICAL MILLING SOLUTIONS

James D. Navratil

Franklin L. Oetting

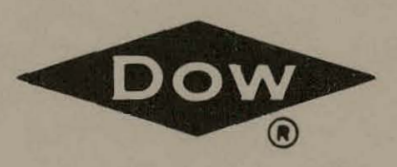

DOW CHEMICAL U.S.A. ROCKY FLATS DIVISION

P. O. BOX 888

GOLDEN, COLORADO 80401

U.S. ATOMIC ENERGY COMMISSION

CONTRACT AT(29-1)-1106 


\section{DISCLAIMER}

This report was prepared as an account of work sponsored by an agency of the United States Government. Neither the United States Government nor any agency Thereof, nor any of their employees, makes any warranty, express or implied, or assumes any legal liability or responsibility for the accuracy, completeness, or usefulness of any information, apparatus, product, or process disclosed, or represents that its use would not infringe privately owned rights. Reference herein to any specific commercial product, process, or service by trade name, trademark, manufacturer, or otherwise does not necessarily constitute or imply its endorsement, recommendation, or favoring by the United States Government or any agency thereof. The views and opinions of authors expressed herein do not necessarily state or reflect those of the United States Government or any agency thereof. 


\section{DISCLAIMER}

Portions of this document may be illegible in electronic image products. Images are produced from the best available original document. 


\section{LEGAL NOTICE}

This report was prepared as an account of work sponsored by the United States Government. Neither the United States nor the United States Atomic Energy Commission, nor any of their employees, nor any of their contractors, subcontractors, or their employees, makes any warranty, expressed or implied, or assumes any legal liability or responsibility for the accuracy, completeness or usefulness of any information, apparatus, product or process disclosed, or represents that its use would not infringe privately owned rights.

Printed in the United States of America

Available from the

Naliunal Techuical Information Service

U. S. Department of Commerce

Springfield, Virginia 22151

Price: Printed Copy $\$ 3.00$; Microfiche $\$ 0.95$ 
Printed

January 24, 1973
RFP-1985

UC-4 CHEMISTRY

TID-4500 - 56th Ed.

THE HEATS OF SOLUTION OF BERYLLIUM IN

\section{CHEMICAL MILLING SOLUTIONS}

James D. Navratil

Franklin L. Oetting

This report was prepared as an account of work sponsored by the United States Government. Neither the United States nor the United States Atomic Energy Commission, nor any of their employees, nor any of their contractors, subcontractors, or their employees, makes any warranty, express or implied, or assumes any legal liability or reşponsibility for the 2oouraey, oom. pleteness or usefulness of any information, apparatus, product or process disclosed, or represents that its use would not infringe privately owned rights.

DOW CHEMICAL U.S.A.

ROCKY FLATS DIVISION

P. O. BOX 888

GOLDEN, COLORADO 80401

Prepared under Contract AT(29-1)-1106

for the

Albuquerque Operations Office

U.S. Atomic Energy Commission

Calorimetry

Beryllium 
RFP-1985 


\section{CONTENTS}

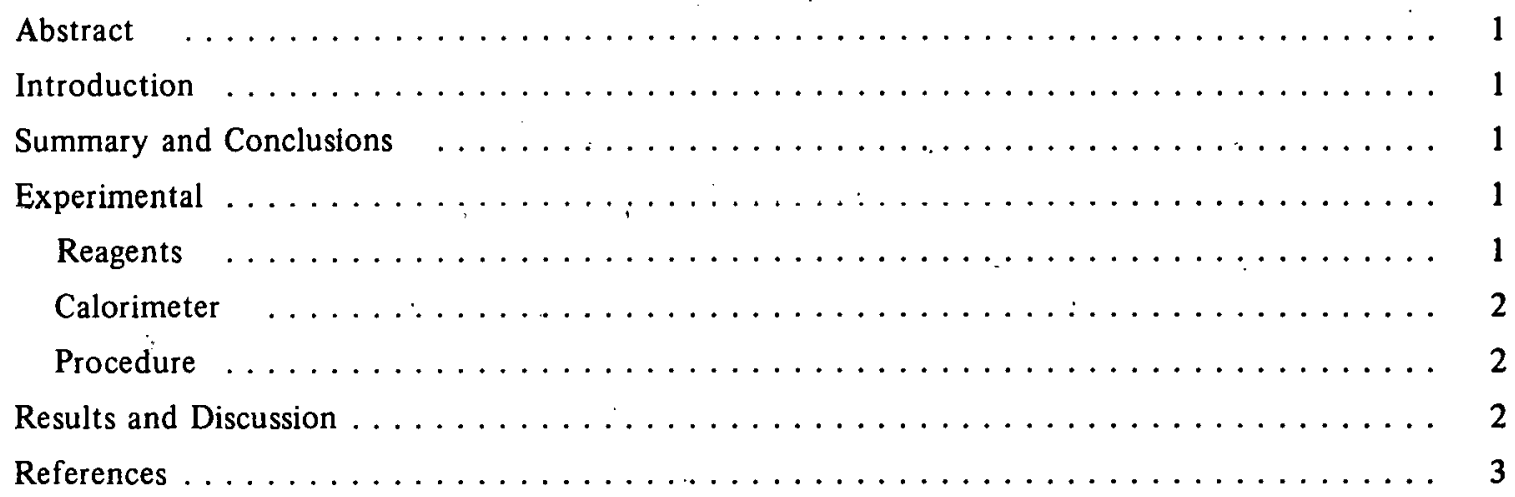


RFP-1985

\section{ACKNOWLEDGMENT}

The authors acknowledge the assistance of R. L. Riegel and E. L. Childs. 


\title{
THE HEATS OF SOLUTION OF BERYLLIUM IN CHEMICAL MILLING SOLUTIONS
}

\author{
James D. Navratil and Franklin L. Oetting
}

\begin{abstract}
The enthalpies of solution of beryllium in chemical milling solutions were measured in an LKB rcaction calorimeter. The enthalpy of $-107.3 \pm 1.3 \mathrm{kcal} \cdot \mathrm{mol}^{-1}$ for a used chemical milling solution containing $\sim 5 \mathrm{~g} / 1$ beryllium was measured at $25^{\circ} \mathrm{C}$ and is compared to an enthalpy of $-119.8 \pm 6.8 \mathrm{kcal} \cdot \mathrm{mol}^{-1}$ for the dissolution of beryllium in fresh milling solution.
\end{abstract}

\section{INTRODUCTION}

A chemical milling solution is presently used to mill beryllium to predetermined dimensions. ${ }^{1}$ During the exothermic chemical milling operation local temperature control of the solution is maintained by cooling coils $\left(\sim 70^{\circ} \mathrm{C}\right)$. Since the milling rate is a function of the temperature, temperature control of the inilling solution is very important. Subsequently, accurate enthalpy values for beryllium in fresh and used chemical milling solutions are necessary for proper design and operation of the cooling coils. Therefore, the enthalpy values of the dissolution of beryllium in fresh and used chemical milling solutions were measured in an LKB reaction calnrimeter.

\section{SUMMARY AND CONCLUSIONS}

The enthalpy of solution of beryllium $(0.11-0.16 \mathrm{~g} / 1)$ in a chemical milling solution (an aqueous solution of $750 \mathrm{ml} / 1$ $\mathrm{H}_{3} \mathrm{PO}_{4}, 31 \mathrm{ml} / 1 \mathrm{H}_{2} \mathrm{SO}_{4}$, and $71 \mathrm{~g} / 1 \mathrm{CrO}_{3}$ ) was measured in an $\mathrm{LKB}$ reaction calorimeter. An enthalpy value of -119.8 $\pm 6.8 \mathrm{kcal} \cdot \mathrm{mol}^{-1}$ was determined at $25.0^{\circ} \mathrm{C}$. Concentration dependence of the heat of solution was found insignificant in the 0.11 to $0.16 \mathrm{~g} / 1$ concentration range. The calculatcd enthalpy of solution of beryllium at $70^{\circ} \mathrm{C}$ is also not significantly different from the above value measured at $25.0^{\circ} \mathrm{C}$. The enthalpy of $-107.3 \pm 1.3 \mathrm{kcal} \cdot \mathrm{mol}^{-1}$ for the used chemical milling solution containing $\sim 5 \mathrm{~g} / 1$ beryllium was measured at $25^{\circ} \mathrm{C}$ and is compared to an enthalpy of $-119.8 \pm 6.8 \mathrm{kcal} \cdot \mathrm{mol}^{-1}$ for the dissolution of beryllium in fresh milling solution.

\section{EXPERIMENTAL}

\section{Reagents}

Two batches of 0.01 -inch-diameter beryllium wire $(0.80 \mathrm{mg}$ beryllium per centimeter of beryllium wire) were used with the fresh chemical milling solution, and a third batch of beryllium wire was used for measurements with the used solution. The first and third batches of beryllium were obtained from Alfa Products, Division of Ventron Corporation; and the second batch was obtained from K\&K Laboratories, Inc. The respective analyses are shown in Table 1.

\begin{tabular}{|c|c|c|c|}
\hline & $\begin{array}{c}\text { Beryllium } \\
\text { No. } 1 \\
\text { (ppm) }\end{array}$ & $\begin{array}{c}\text { Beryllium } \\
\text { No. } 2 \\
\text { (ppm) }\end{array}$ & $\begin{array}{c}\text { Beryllium } \\
\text { No. } 3 \\
\text { (ppm) }\end{array}$ \\
\hline Al & 900 & 850 & 820 \\
\hline $\mathrm{C}$ & 285 & 220 & 120 \\
\hline $\mathrm{Cl}$ & 250 & 112 & 112 \\
\hline $\mathrm{Cr}$ & 30 & 50 & 70 \\
\hline $\mathrm{Cu}$ & 50 & 50 & 50 \\
\hline $\mathrm{Fe}$ & 800 & 1300 & 725 \\
\hline $\mathrm{Mg}$ & 170 & 210 & 30 \\
\hline Mn & 190 & 110 & 90 \\
\hline $\mathbf{N}$ & 22 & 55 & 25 \\
\hline $\mathbf{N i}$ & 130 & 70 & 180 \\
\hline 0. & 828 & 665 & 170 \\
\hline $\mathrm{Si}$ & 750 & 900 & 550 \\
\hline Ti & 160 & 200 & 190 \\
\hline All Others & $<310$ & $<300$ & $<140$ \\
\hline Difference (Mass \%) & 99.436 & 99.430 & 99.650 \\
\hline Clıcmical Assay (Mass \%) & $y y .40$ & 99.18 & 99.65 \\
\hline
\end{tabular}

The beryllium assay was determined in duplicate by ammonium fluoride titration after hydrochloric acid dissolution. The percent beryllium does not include beryllium as refractory BeO. The impurities were determined in duplicate by spark source mass spectroscopy and emission spectroscopy. The average major impurities are shown in Table 1. The percent beryllium taken by difference of the total impurities, where $\mathrm{C}, \mathrm{N}$, and $\mathrm{O}$ were assumed to be chemically combined with beryllium, is in excellent agreement with the chemical assay results except for the second batch. The percent beryllium obtained by difference was the more accurate and was used to correct the beryllium weights for impurities. Heat contributions from the reactive metallic impurities $\left(\sim 15 \mathrm{cal} \cdot \mathrm{mol}^{-1}\right)$ were neglected since they would not significantly change the beryllium enthalpy results.

The fresh chemical milling solution (designated $A$ ) had the following composition: $750 \pm 1 \mathrm{ml} / \mathrm{l}$, Precision Chemical 
Corporation, reagent ACS, ortho phosphoric acid (85-87\%); $71 \pm 0.5 \mathrm{~g} / 1$ Baker reagent chromium trioxide $(99.7 \%)$; $31 \pm 0.5 \mathrm{ml} / 1$ Baker "Ultrex" sulfuric acid (99.3\%); and the balance (to $1.0 \pm 0.002 \mathrm{l}$ ) distilled water. The used chemical milling solution (designated $\mathrm{B}$ ) was composed of $\sim 4 \mathrm{~g} / \mathrm{l} \mathrm{Be}$; $750 \pm 15 \mathrm{ml} / 1 \mathrm{H}_{3} \mathrm{PO}_{4}$ (85-87\%); $71 \pm 2 \mathrm{~g} / 1 \mathrm{CrO}_{3}$ (99\% technical flake); $30 \mathrm{ml} / 1 \mathrm{H}_{2} \mathrm{SO}_{4}(95-98 \%)$; and $200 \pm 5 \mathrm{ml} / 1$ de-ionized water. A solution (designated $\mathrm{C}$ ) identical to $\mathrm{B}$, except containing no beryllium, was also used.

\section{Calorimeter}

A modified LKB reaction calorimeter of the isoperibol type was used for the measurements. Details of the description and operation of the calorimeter may be found elsewhere. ${ }^{2}$ The precision and accuracy of the calorimeter was determined by one standard fast reaction and a known slow reactinn The enthalpy of the calorimetric standard reaction, the neutralization of TRIS [tris-(hydroxymethyl)aminomethane] SRM 724 in excess $0.1 N$ hydrochloric acid, was determined under conditions recommended by the National Bureau of Standards. ${ }^{3}$ Our value of $-7109 \pm 4 \mathrm{cal} \cdot \mathrm{mol}^{-1}$ is is in excellent agreement with values reported by Fitzgibbon and Holley $\left(7111 \pm 5 \mathrm{cal} \cdot \mathrm{mol}^{-1}\right),{ }^{4}$ Gunn $\left(7107 \pm 1 \mathrm{cal} \cdot \mathrm{mol}^{-1}\right){ }^{5}$ and Sunner, et al. $\left(7110 \pm 1 \mathrm{cal} \cdot \mathrm{mol}^{-1}\right){ }^{6}$

A slower known reaction ( $\Delta t \simeq 24$ minutes) was also measured because it had a comparable reaction time to the beryllium-chemical milling solution reaction time. The enthalpy of dissolution of beryllium $(0.12 \mathrm{~g} / \mathrm{l})$ in $1.0-1.2 \mathrm{M}$ sulfuric acid was determined at $25.0^{\circ} \mathrm{C}$ as $-91.814 \pm 0.085$ $\mathrm{kcal} \cdot \mathrm{mol}^{-1}$. This value is only in fair agreement with the

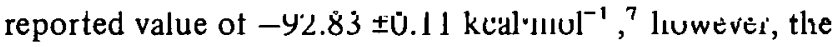
calculated heats of formation for beryllium sulfate and its hydrates resulting from our enthalpy of dissolution results were found to be in better agreement with other studies. ${ }^{2}$ This indicated that the calorimeter was performing properly under these conditions.

\section{Procedure}

A typical run consisted of breaking a one milliliter glass ampoule containing the beryllium wire into $99.8 \pm 0.1 \mathrm{ml}$ of chemical milling solution at $25.000 \pm 0.001^{\circ} \mathrm{C}$. Calibration runs followed the experimental runs and consisted of supplying to the heater a known amount of power to match the temperature rise of the reaction. The corrected temperature rise was determined via a computer program by the Regnault-Pfaundler calculation method.?

\section{RESULTS AND DISCUSSION}

All results are expressed in defined calories ( 1 calorie $=$ 4.184 abs joules). All sample weights werc corrected to true mass (using 1.848 for the density of beryllium), and the formula weight of 9.01218 for beryllium was used.

Uncertainties stated are twice the standard deviation of the mean, $2\left\{\Sigma d^{2} / n(n-1)\right\}^{1 / 2}$.

Table 2 contains the experimental enthalpy data using the three batches of beryllium. Experiments number one and six were not included because of instrument problems during the calibration run.

Table 2. Enthalpy of Solution Data for Beryllium in $99.8 \mathrm{ml}$ of Chemical Milling Solutions.

\begin{tabular}{|c|c|c|c|c|c|}
\hline $\begin{array}{l}\text { Experiutient } \\
\text { No. and } \\
\text { Snlutinn } \\
\text { Designation a }\end{array}$ & $\begin{array}{l}\text { Mass of } \\
\text { Rervilium }^{b} \\
(\mathrm{mg})\end{array}$ & $\begin{array}{c}\epsilon^{\mathrm{c}} \\
\left(\mathrm{cal} \cdot \mathrm{K}^{-1}\right)\end{array}$ & $\begin{array}{c}\Delta \mathrm{T}^{\mathrm{d}} \\
\left(\mathrm{K}^{-1}\right)\end{array}$ & $\frac{\Delta t^{\mathrm{e}}}{(\min .)}$ & $\begin{array}{c}-\Delta \mathrm{H} \\
\left(298.15^{\circ} \mathrm{K}\right) \\
\left(\mathrm{kcal} \cdot \mathrm{mol}^{-1}\right)\end{array}$ \\
\hline $2 \mathrm{~A}$ & 11.077 & 79.115 & 1.7926 & 63.1 & 115.4 \\
\hline $3 A$ & 11.196 & 79.516 & 1.9046 & 69.0 & 122.3 \\
\hline $4 \mathrm{~A}$ & 11.226 & 79.427 & 1.6848 & 74.3 & 107.4 \\
\hline $14 \mathrm{~A}$ & 11.759 & 79.265 & 1.8655 & 56.7 & 113.3 \\
\hline $15 \mathrm{~A}$ & 11.700 & 79.466 & 1.8027 & 60.2 & 110.3 \\
\hline $5 \mathrm{~A}$ & 15.936 & 78.859 & 2.4478 & 65.0 & 109.2 \\
\hline $7 \mathrm{~A}$ & 15.697 & 79.586 & 2.4498 & 68.1 & 111.9 \\
\hline $8 \mathrm{~A}$ & 15.727 & 79.819 & 2.4265 & 62.8 & 111.0 \\
\hline $9 A$ & 15.817 & 79.977 & 2.8456 & 55.7 & 129.7 \\
\hline $10 \mathrm{~A}$ & 16.333 & 79.185 & 2.6378 & 59.7 & 115.1 \\
\hline $11 \mathrm{~A}$ & 16.323 & 79.060 & 2.6476 & 60.1 & 115.6 \\
\hline $12 \mathrm{~A}$ & 16.512 & 79.064 & 2,5503 & 61.0 & 110.0 \\
\hline $13 \Lambda$ & 15.627 & 79.402 & 3.2997 & 44.4 & 151.1 \\
\hline $20 \mathrm{C}$ & 11.893 & 83.348 & $2: 2906$ & 50.6 & 144.7 \\
\hline 216 & 11.813 & 82559 & 2.1977 & 55.7 & 137.2 \\
\hline $22 \mathrm{C}$ & 11.883 & 83.641 & 1.7864 & 63.9 & 113.3 \\
\hline $16 B$ & 12.033 & 82.871 & 1.7469 & 69.8 & 108.4 \\
\hline $17 \mathrm{~B}$ & 11.973 & 84.231 & 1.6977 & 72.4 & 107.6 \\
\hline $18 B$ & 11.784 & 84.118 & 1.6738 & 70.0 & 107.7 \\
\hline $19 \mathrm{~B}$ & 11.764 & 84.182 & 1.6350 & 76.0 & 105.4 \\
\hline \multicolumn{6}{|c|}{$\begin{array}{l}a_{\text {Fresh }}(A, C) \text { and used }(B) \text { solutions. } \\
{ }^{b} \text { Corrected to true mass and for impurities. Experiments } 2 \text { through } \\
9,14 \text {, and } 15 \text { used Beryllium Batch No. } 1 \text {; Experiments } 10 \text { through } \\
13 \text { used Beryllium Batch No. 2; and Experiments } 16 \text { through } 19 \\
\text { used Beryllium Batch No. } 3 \text {. } \\
c_{E} \in \text { is the electrical energy equivalent. } \\
d_{\Delta T} \text { is the corrected reaction temperature change. } \\
e_{\Delta t \text { is the corrected reaction time. }}\end{array}$} \\
\hline
\end{tabular}

The enthalpy values were not corrected for the heat absorbed $\left(0.4 \mathrm{kcal} \cdot \mathrm{mol}^{-1}\right)$ when the water was vaporized by the escaping hydrogen because the noncorrected value is more representative of the heat generated during the chemical milling operation. The heat of ampoule breaking, heat 
of vaporization, etc., $\left(\sim 1 \mathrm{cal} \cdot \mathrm{mol}^{-1}\right)$ were found insignificant for the magnitude of the enthalpy values reported here. ${ }^{2}$

The average enthalpy value $\left(-119.8 \pm 6.8 \mathrm{kcal} \cdot \mathrm{mol}^{-1}\right)$ for fresh chemical milling solutions is independent of the batch of beryllium (No. 1, 2, 3), the batch of chemical milling solution $(A, C)$, and the weight of the beryllium ( 0.11 to $0.16 \mathrm{~g} / \mathrm{l})$ used. However, erratic results were obtained with the fresh chemical milling solutions and account for the comparatively high error limit. Since relatively normal, electrical-energy equivalents and heat-leakage constants were observed, the erratic results could not be attributed to significant experimental measurement errors but are attributed to unknown side reactions.

Because the actual chemical milling operation is performed at $70^{\circ} \mathrm{C}$, the $\Delta \mathrm{H}\left(280.15^{\circ} \mathrm{K}\right)$ of $-120.0 \pm 6.8 \mathrm{kcal} \cdot \mathrm{mol}^{-1}$ for the fresh solution was estimated using a $\Delta \mathrm{Cp}$ of 3.93 $\mathrm{cal} \cdot \mathrm{deg}^{-1} \cdot \mathrm{mol}^{-1}$. $^{8}$

The average enthalpy of solution $\left(-107.3 \pm 1.3 \mathrm{kcal} \cdot \mathrm{mol}^{-1}\right)$ for the used solution is apparently different than the heat of solution for the fresh solutions. However, since the batch of beryllium wire was different as well as the grade of materials comprising the used chemical milling solution, several runs (20-22) were made duplicating these conditions. Since these latter results are charactcristic of data frül runs $1-12$, it was concluded that the heats of solution between the fresh and used chemical solutions are significantly different.

The difference between the fresh and used chemical milling solution is also evident in the reaction times. The reaction times per gram of beryllium $(\Delta t / g)$, comparing the runs using $12 \mathrm{mg}$ of beryllium, were significantly different for the fresh chemical milling solution ( $5.34 \pm 0.56$ min./g) opposed to the used chemical milling solution (6.06 $\pm 0.28 \mathrm{~min} . / \mathrm{g}$ ).

Different reaction(s) occurring in the fresh chemical milling solution opposed to the used solution could account for the different enthalpies obtained. A similar explanation is also attributed to the erratic enthalpy results obtained with the fresh solution. The chemistry of these systems is very complex. Results of the chemical analyses of $\mathrm{Cr}^{3+}, \mathrm{Cr}^{6+}$, and $\mathrm{H}^{+}$did not differ significantly between the fresh and used solutions. Therefore, no further attempts were made. to elucidate the reactions involved. However, the enthalpies obtained are a valuable aid in the design of cooling coils.

\section{REFERENCES}

1. R. L. Riegel, E. L. Childs, and K. R. Souply, private communication, Rocky Flats Division, Dow Chemical U.S.A., January 8, 1970.

2. J: D. Navratil and F. L. Oetting, Rocky Flats Division, Dow Chemical U.S.A., to be published.

3. E. J. Prosen and M. V. Kilday, private communication, National Bureau of Standards, Washington, D.C., October 1971.

4. G. C. Fitzgibbon and C. E. Holley, Jr., private communication, Los Alamos Scientific Laboratory, Los Alamos, New Mexico, January 1968.

5. S. R. Gunn, J. Chem. Thermodynamics, 2, 535 (1970).

6. J. Laynez, B. Ringner, and S. Sunner, J. Chem. Thermodynamics, 2,603 (1970).

7. A. R. Taylor, Jr., B. B. Letson, and D. F. Smith, U. S. Department of the Interior, Bureau of Mines, RI 6724 (1966).

8. V. B. Parker, D. D. Wagman, and W. H. Evans, NBS Technical Note 270-6, National Bureau of Standards, Washington, D.C., Nuvember 1971. 